УДК 911.7(477.75) + 81’286+14 + 94(470)

\title{
Voltaire's Onomomyths \\ in Russian Literary Consciousness \\ of the Enlightenment
}

\author{
Elena E. Prikazchikova* \\ Ural Federal University named after the B. N. Yeltsin \\ 19 Mira Str., Ekaterinburg, 620002, Russia
}

Received 22.12.2014, received in revised form 19.01.2015, accepted 29.04.2015

The paper gives the analysis of five Voltaire's onomomyths, created by literary mentality during the Age of Enlightenment in Russia. On the basis of investigation of these onomomyths, interpreting Voltaire as a fighter with religious fanaticism, as a plenipotentiary minister of the Hell, as a leader of liberals, as an inspirer of "Voltairian" suicides, as an organizer of the French revolution, the author comes to the conclusion about non-historical character of cultural creation of myths. The present creation of myths in new literary-historical conditions can regenerate and develop old plots, associated with the eternal problem of interrelation of personality and society.

Keywords: Voltaire, onomomyths, the Age of Enlightenment, cultural mythology.

DOI: 10.17516/1997-1370-2015-8-7-1469-1478

Research area: philology.

\section{Introduction}

The Enlightenment as the era of the triumph of reason is considered to be antimythological era compared to the first decades of the $19^{\text {th }}$ century or the beginning of the $20^{\text {th }}$ century, with their active literary mythmaking position. However, in the theoretical study of the problems of myth-making, it is important to separate myth-making as a real process of literary consciousness of the era and analytical understanding of the role of the myth in scientific consciousness of any literary movement. For the latter it seems productive to use the term "philosophy of myth". From this perspective, one can find justifiable the view of V.M. Naidysh that even in the era of classicism "the myth appeared as a kind of conscious, rational and ideological creativity of the subject" (Naidysh, 2002, p. 405).

Ideologized myth-making of the Enlightenment realized itself in the phenomenon of cultural myth, which is a word (the term "myth" is translated as "a word" from Greek) about the world, functioning within a certain subculture of a particular literary and historical era and which is found in the literature works par excellence. The collection of all cultural myths creates a certain model of the world, which is proper for this very literary era.

(C) Siberian Federal University. All rights reserved

* Corresponding author E-mail address: nkovtun@mail.ru 


\section{Theoretical framework}

Theoretical understanding of the problem of myth-making in the $18^{\text {th }}$ century was proposed by V.M. Zhivov, B.A. Uspenskii, A.M. Panchenko. From the works of the last decade the most important are monograph "Nina. The cultural myth of the golden age of Russian literature in the linguistic coverage" by A.B. Pen'kovskii, monograph "The life of manor myth: paradise lost and found" by E.E. Dmitrieva and O.N. Kuptsova, monograph "Feeding the double headed eagle": literature and state ideology in Russia of the last third of the $18^{\text {th }}$-the first third of the $19^{\text {th }}$ century" by A.L. Zorin, monograph "Myths of the Empire: literature and the power in the era of Catherine II" by V.Iu. Proskurina, monograph "Poetic mythology of the $18^{\text {th }}$ century. Lomonosov. Sumarokov. Kheraskov. Derzhavin" by T.E. Abramzon. Among works of foreign authors, which are related to the myth-making of the $18^{\text {th }}$ century, we can distinguish highly informative works by R.S. Wortman "Scenarios of power. Myths and ceremony of the Russian monarchy, from Peter the Great to the death of Nicholas I" and L. Wolff "Inventing Eastern Europe. Map of civilization in the consciousness of the Enlightenment". These works involve a variety of aspects of cultural myth-making of the $18^{\text {th }}$ century: the state myth, manor myth-making as a version of the park and garden myth of the Enlightenment, poetic mythology of the leading Russian writers of the $18^{\text {th }}$ century, the cultural mythology of ethnic relations and creating an image of Eastern Europe in the Western European consciousness. In all cases, the primary objective of the authors was to analyze the mythmaking mechanism, which manifests itself in different aspects of social and political life of the Enlightenment, being reflected in a range of literary monuments of this time as artistic reflections, including travel literature, memoirs and epistolary works.

\section{Voltaire's onomomyths in the context of the perfect man myth}

A central place among the cultural myths of the Age of Enlightenment is taken by the myth of the Man, or rather the myth of the Perfect Man. This is fully in line with the specifics of educational aesthetics, where as A.P. Valitskaia rightly considered, a man "appears as a "goal" of the movement of nature to perfection and at the same time as a "means" of improving the world" (Valitskaia, 1983, p. 8).

There is a fundamental difference between a myth and a cultural anthropological utopiaeupsychia of the $18^{\text {th }}$ century. The utopiaeupsychia considers an alternative embodiment of human existence in the modern world, allocating a special place to the ideal education of the person (the utopia of the Smolny Institute, the $1^{\text {st }}$ Cadet Corps in St. Petersburg). Cultural mythology of the ideal man often deals with onomomyths - myths of the name, where the possible models can be the names of the rulers (the mythology of Peter the Great as God-demiurge, creating a New Russia), ancient heroes, whose behavior in the context of the myth-creating culture of the $18^{\text {th }}$ century is thought to be exemplary (Horace Cocles, Muzio Scaevola, Quirin Curtius), philosophers (Seneca, Socrates, Voltaire).

The followers of Voltaire were one of the most representative noble subcultures in the $18^{\text {th }}$ century - Voltairiens, who supposed that, according to American historian D. H. Billington, "multifaceted French Enlightenment seems completely integrated, and Voltaire is placed in its heart" (Billington, 2001, p. 270).

Voltaire as "the century's tribune" (according to A.A. Bestuzhev-Marlinskii), "the minds' and fashion's leader" (according to A.S. Pushkin) retained his "intellectual yoke" over the reading Russians until the era of A.S. Pushkin, who himself in youth experienced a passion for "Ferney patriarch". 
At the same time least of all Voltaire's onomomyths were associated with a real biography of person Francois-Marie Arouet, who, in the view of A. Stroev, was a striking embodiment of the type of adventurer who made his fortune not by work, but by often not too plausible speculations" (Stroev, 1998, p. 70). As an object of cultural mythologizing in the Age of Enlightenment, Voltaire spawned a number of onomomyths, whose analysis in the literary consciousness of Russia in the second half of the $18^{\text {th }}$ century is the purpose of our paper.

\section{Voltaire as the leader of the Enlightenment}

\section{and a fighter against religious fanaticism}

The first, closest to the truth onomomyth about Voltaire in Russia is that he was a great writer and leader of the Enlightenment, a fighter with medieval feudal superstitions and religious fanaticism. In Russia, the honour of the "discovery" Voltaire belongs to the Empress Catherine II, about whom Berdyaev rightly said: "Catherine the Great was Voltairienne" (Berdyaev, 1997, p. 17). Correspondence of Catherine II with Voltaire, which lasted until the philosopher's death is a clear confirmation of this fact. We can say that in her letters the Russian Empress set a model of an ideal perception of Voltaire, which was formed in Russian society.

In these letters, Catherine II, on the one hand, all the time called Voltaire the greatest writer of his time, and admitted that since 1746 she had not read any other books besides his works, considering them "the last limits of French literature" (Philosophical ... correspondence, 1802, p. 188).

On the other hand, Catherine II creates a cultural myth of Voltaire as a person worthy "the immortal name" because he was "an intercessor for the human race and the defender of the oppressed innocence" (Philosophical ... correspondence, 1802 , p. 18). Voltaire for the Russian Empress became a symbol of the European Enlightenment, while she sees herself as a true disciple of the great "Ferney patriarch", thus developing educational state myth about "a philosopher on the throne".

\section{Voltaire - \\ plenipotentiary minister of hell}

The second onomomyth about Voltaire in Russia is a cultural myth of Voltaire-atheist, "plenipotentiary minister of hell". In the context of these ideas Voltaire, being a symbol of the "negation of the existing axiological system" acted "as a symbol of freethinking and even atheism" (Ovchinnikova, 2001, p. 175).

This view of Voltaire had little to do with the real work of Voltaire and the personality of French educator. As everyone knows, real Voltaire was never a real atheist. In his poem "On natural law", which was finished with deistic "Prayer", he rejects not only the religious fanaticism, but also atheism. The myth of the godless Voltaire resulted from anti-Voltaire propaganda, which was inspired simultaneously by the Masons and the representatives of the so-called "national" party, led by Count Panin, and which included the writer D.I. Fonvizin. Therefore, Fonvizin's works give a lot of representative material for the study of the phenomenon of "temptation" by Voltairianism. For example, Ivan, a character in Fonvizin's comedy "Brigadier" allows naturally "Voltairian" quotes for himself. He expressed confidence that "God has left to the human a volition - to love, to betray, to get married and get divorced" (Fonvizin, 1989, p. 34); he said that "he used to know ... a big set of different people who bid defiance to oaths" (Fonvizin, 1989, p. 51). These statements of Ivan, taken out of comedy context, are not funny in themselves, as one can see behind them the shadow of freethinking 
France, bequeathed to Europe by Voltaire himself.

Fonvizin also refers to Voltairianism in "The Minor", especially when there is a problem of the true and sham enlightenment in the comedy. The goodie Starodum tells his niece Sophia: "I fear the current sages for you. In spite of their strong eradication of prejudice, they also uproot the virtue" (Fonvizin, 1989, p. 125).

In "The sincere confession of my deeds and thoughts", a confession-repentance of palsied writer, Fonvizin begins to believe his illness which struck him at the age of 40 years to be the God's punishment for Voltairian freethinking in youth. The symbol of this freethinking is Fonvizin's visits of a literary circle of Prince F. Kozlowski, where "the best pastime consisted of blaspheming and sacrilege" (Fonvizin, 1959, p. 95). Fonvizin considers as an example of such a "sacrilege" primarily his "Message to my servants: Shumilov, Van'ka and Petrushka", where the most "Voltairian" is the position of the barber Petrushka, who prefers to see in the world around him a puppet theater, where as the Creator acts as the director-puppeteer.

\section{Voltaire - the leader of the Libertines}

The third onomomyth about Voltairianism has been associated with the idea of Voltaire as a libertinism leader, a preacher of immorality and free love. This aspect is the most interesting in the context of Russian culture, as real Voltaire despite all the cynicism attributed to him was by no means an apologist for immorality in the issue of gender relations.

Libertinism phenomenon, understood as "freedom of manners", could not be fully reflected in the literature of the $18^{\text {th }}$ century because of the censored image of such scenes. However, in everyday life libertinism was express in the "Voltairian" Europeanism of Russian nobles who kept harems of serfs, sincerely believing that in this case they act Voltairian, namely without prejudice, which characterized the pre-Peter time.

Many echoes of this "fashionable" Voltairianism can be found in memoirs and autobiographical literature of the Enlightenment, which allowed the authors to exercise maximum self-reliance and independence in terms of their point of view. For example, in the writings of "Ural mason" A.E. Labzina titled "History of the life of a noble woman" the plot and structure are based on a dramatic spiritual conflict between Labzina and her first husband Alexander Karamyshev. This conflict was largely predetermined by the situation of their cultural confrontation. The characters of these writings belong to different cultural branches of the "multifaceted" $18^{\text {th }}$ century, whereas A. Karamyshev personified the very Voltairian culture. "The trouble" of Karamyshev, a talented scientist and mining engineer, having received an excellent European education at Uppsala University in Sweden, was that in the field of moral philosophy, he was a hedonist, seeking pleasure for itself, and not denying the right of others to this hedonism. Being married to 13-year-old girl brought up in strict religious traditions, Karamyshev wanted to recreate her as a teacher and educator who, like Pygmalion, would create a new Galatea for himself.

Therefore, immediately after the marriage, he engaged in "re-education" of his young wife, guided by morality of a "gallant" Voltairian century. Having fun with "the girls" Karamyshev did not require faithfulness from his wife, and advised the memoirist to have a lover, whose selection he was ready to take over. Karamyshev's philosophy is a typical, Voltairian philosophy of hedonism, as it was understood in Russia in the second half of the $18^{\text {th }}$ century. The husband repeatedly said to her: "There is no $\sin$ 
and shame to have fun in our life!" (Labzina, 1996, p. 60).

D.I. Fonvizin in the same "The sincere confession...", describing the sins of his youth, says that at this time he fell a victim of seductive novels. And although he does not mention the name of Voltaire, one can guess from the context and the wordings used by the memoirist that he had in mind Voltaire's novel "Candide". The whole scene of the failed author's seduction of a Moscow girl, who could only be described as: "fat, fat! simple, simple!" is rendered by the writer in an ironic "Candide-like" spirit: "I wish I taught her some physical experiments (emphasis added), but there was no a convenient spot for it, the doors in her mother's house, being made by national artists, could neither be shut, nor closed" (Fonvizin, 1959, p. 89).

Let us recall the scene from the novel by Voltaire, which is projected in this case by Fonvizin. It is completely devoid of any frivolity in the spirit of rococo and is really quite far from the traditions of Russian obscene funny verses or "experience" of the Marquis de Sade. There is no "indecent" speech in it, no hint of the essence of the lessons of "Experimental Physics", which Dr. Pangloss gives to the maid of Kunigunde's mother, while she is walking in the woods near the castle. However, this scene made an indelible impression on the minds of the people of the Enlightenment, causing them to consider Voltaire "seducer" and to create a cultural myth about his exceptional depravity.

\section{Voltaire - inspirer of idea suicides}

The fourth onomomyth of Voltaire has been associated with the phenomenon of suicide for ideological reasons due to the man's loss of faith in the soul's immortality. The problem with the nature of the human soul was described by Voltaire in his famous "Treatise on Metaphysics", where Voltaire said: "I do not claim that I have evidence refuting the spirituality and immortality of the soul; but all probability is against them" (Voltaire, 1996, p. 155).

These enlightenment-like doubts gave rise to the most tragic cultural myth about Voltaire, presented in Russia as follows: if there is no immortality of the soul, and, perhaps, God, the life is not worth living at all. A prime example of realization of this cultural myth in everyday life and at the literary level is the life and death of the Russian writer, sentimentalist M.V. Sushkov, who committed suicide in 1792 at the age of just 17 years. Sushkov was the author of the autobiographical novel "The Russian Werther", in which he recreated the phase of "temptation by Voltairianism" and ... the tragic end of this temptation. Young noble and educated Sushkov committed a suicide, which caused a great resonance in Russian society, as in his deathbed will people saw the manifestation of the influence of "the French contagion", full of atheism and freethinking. I can cite very characteristic in this respect N. Bantysh-Kamensky's letter to Prince A.B. Kurakin, whose author exclaimed indignantly: "Read his letter: how many curses to the Creator! What arrogance and self-exaltation!" (Bantysh-Kamensky, 1876, p. 274).

Indeed, the deathbed will was written by M. Sushkov with an eye to the unconditional "Voltairian faith". Interestingly, the main pathos of the will in some "subdued" form is already present in the will of the hero of his autobiographical novel "The Russian Werther". The novel tells: "He ordered to give the remaining money, according the attached note, to the poor, and nothing to the priests (italics mine), and so the poor with tears accompanied him to the place where he was laid, and the priests gave malediction to his name" (Sushkov, 
1979, p. 222). Iu.M. Lotman characterized the attitude of a person living inside this Voltairian myth: “... He turned out to be vis-a-vis, face to face with eternity. It was a delightful and strange feeling" (Lotman, 1994, p. 215). This "delightful" and "strange" feeling infected the young Yaroslavl nobleman Ivan Opochinin, who shot himself six months after the death of M. Sushkov, on January 7, 1793. His suicide note left for his brother, was named by L.N. Trefolev, the researcher of the $19^{\text {th }}$ century, "the deathbed will of a Russian atheist". Opochinin, among other things, wrote in it: "Death is nothing else like the passage from being to the complete destruction of $<\ldots>$ After the death there is nothing! $<\ldots>$ This fair and appropriate to the surest rule of reason ... forced me to take a gun in my hand" (cited Trefolev, 1883, pp. 224-225). At the end of his will Opochinin put his "'Prayer", which is the translation of Voltaire's "The Prayer" from the final of the poem "On natural law", the characteristic works of deist Voltaire, in which the philosopher realized his dream of unified and universal philosophical religion.

The question here arises whether it is possible to deduct from the philosophical works of Voltaire a valid call for suicide, resulting from an awareness of the absolute freedom of the person and this person's abandonment by God? According to Voltaire: “... if we had always been free, we would have been what God is. Let us rather accept the fate corresponding to the place occupied by us in nature" (emphasis added) (Voltaire, 1996, p. 159). This Voltaire's statement is not at all reminiscent of defiant challenge to the heavens. Another thing is that Voltaire truly believed that God does not care what is done on earth, and this deism led to despair among Russian Voltairiens. Ideological suicides "for Voltairian" reason symbolized the end of an era of Voltaire triumphal march through Russia, the end of the official and semi-official Voltairianism era.

\section{Voltaire - the organizer of the French Revolution}

The fifth Voltairian onomomyth of Russian culture is the myth of Voltaire as an organizer of the French Revolution. Empress Catherine II, the former "Voltairienne" herself participated in creating this myth, pointedly ordering during the Jacobin dictatorship to bring a bust of Voltaire out of her study. Russian Masons fully agree with the Empress in this case. One can remember I.V. Lopukhin's letter to A.M. Kutuzov, dated October 14, 1790: "I think that the works of Voltaires, Diderots, Helvetiuses, and many of the anti-Christian freethinkers contributed greatly to the current mad actions (i.e. revolution) in France" (Letters of Russian Freemasons, 1922, p. 183). Derzhavin's friend metropolitan Eugene Bolkhovitinov in the era of Jacobin terror lamented about the "poison of Voltaire", which was poured out from France, from "the most outrageous and wicked Voltaire's books" (cited ex: Borodin, 1887, p. 75). Voltaire as a depraver of the human race was discussed by Russian educator and memoirist Bolotov. Paying tribute to "the treasures of the great mind" of Voltaire, he accused him of overthrowing of the moral foundations of the society, and called the philosopher "monster and depraver of the human race" (Bolotov, 1986, p. 602).

Meanwhile, to be honest, the title of "the organizer of the revolution" rightfully belongs to J.J. Rousseau as the author of "Social Contract" (1762). That is utopia-eunomia, and the attempt to implement that in practice was undertaken during the French Revolution. Among its leaders "the idea of the complete destruction of the old order and arrangement of society from scratch, with filling tabula rasa as required by common sense, rather than a custom or tradition" was quite popular (Chudinov, 2000, p. 53). From this perspective, French revolutionaries were ready to equate any misconduct in morals to a counter- 
revolutionary act, and the terror was seen as the main means of resolving the conflict between Virtue and Vice. The fact that the Kingdom of the Mind, the notorious Century of Philosophers, led in the end to the terror of the French Revolution, gave rise to bitter reflections of N.M. Karamzin in 1795. He expressed them in the words of his hero Melodor: "The Age of Enlightenment! I do not recognize you, among murders and destruction I do not recognize you!" (Karamzin, 1982, p. 149).

Despite the fact that Voltaire, as well as his books, had nothing to do directly with these murders and destruction, however, since the era of the French Revolution Russia publishers have begun to publish books denouncing "Ferney patriarch", for example, "Voltaire uncovered" (1792), "Voltaire's delusion" (1793), "Protection from unbelief and wickedness" (1794), "Oracle of new philosophers, or who is Mr. Voltaire" (1803).

Attempts of objective analysis of Voltaire's creativity and his philosophy were first made only in the first third of the $19^{\text {th }}$ century, when Voltaire himself had already become history.

\section{Conclusions. Voltaire forever}

Five onomomyths about Voltaire, analyzed in this paper, reflect the cultural mythmaking mechanism of the Enlightenment. However, the myth-making associated with the name Voltaire, was not limited to the $18^{\text {th }}$ century only. So, in the $19^{\text {th }}$ century political mythology of Voltairianism was rather popular, as it recreated the myth about Voltaire as the organizer of the French Revolution in the new historical conditions. This fact has allowed academician M.V. Nechkina to conclude:
"Voltaire is a kind of participant of the Russian liberation movement", 'employee' of Russian progressive social thinking” (Nechkina 1948, p. 93). In the $20^{\text {th }}$ century, in an attempt to see in Voltairianism some dominant philosophical and ideological discourse and everyday discourse of the $18^{\text {th }}$ century V. Aksenov wrote his novel "Voltairiens and Voltairiennes" (2004).

Subject of Voltaire is still current in the West, which may contribute to the birth of new onomomyths associated with his name, or to the revival of the old ones. Only during last 15 years in the West have been published the following books: "Voltaire. A Life" by Ian Davidson (2010), The "Cambridge Companion to Voltaire" by Nicholas Cronk (2009), "Voltaire Revisited" by Bettina L. Knapp (2000), "The Mind and the Market: Capitalism in Western Thought" by Jerry Z. Muller (2002), "Voltaire Almighty: a life in pursuit of freedom Roger Pearson" (2005). For instance, Canadian scholar and writer D.R. Sol in his book "Voltaire's Bastards. Dictatorship of Reason in the West", written in the early $90 \mathrm{~s}$ of the $20^{\text {th }}$ century, claimed: “... if Voltaire were transported in our time, new structures, which have distorted the ideals for which he fought completely, would cause his anger" (Sol, 2007, p. 1). With his talent D.R. Sol revives the myth of Voltaire a fighter with the "oppressed innocence", as Catherine II imagined in the $18^{\text {th }}$ century. This means that onomomyths about Voltaire - a writer and philosopher, symbolizing the Age of Enlightenment, have not lost their relevance in our time, when the struggle for the ideals of the Enlightenment, especially in literature, is full of new meaning and content.

\section{References}

1. Abramzon, T.E. Poeticheskie mifologii XVIII veka. Lomonosov. Sumarokov. Kheraskov. Derzhavin: monografiia [Poetic mythology of the $18^{\text {th }}$ century. Lomonosov. Sumarokov. Kheraskov. Derzhavin: monograph]. Magnitogorsk: Magnitogorsk State University, 2006. 480 p. 
2. Aksenov, V. Vol'ter'iantsy i vol'ter'ianki [Voltairiens and Voltairiennes]. M., Izografus, 2005. $555 \mathrm{p}$.

3. App, U. The Birth of Orientalism. Philadelphia: University of Pennsylvania Press, XVIII +, 2010. $550 \mathrm{p}$.

4. Bantysh-Kamenskii, N.I. (1876). Moskovskie pis'ma v poslednie gody Ekaterininskogo tsarstvovaniia [Moscow letters in recent years of the reign of Catherine]. Russkii arkhiv (Russian archive), 11. Pp. 257-285.

5. Berdyaev, N.A. Russkaia ideia. Sud'ba Rossii [Russian idea. The fate of Russia]. M., Svarog and Co, 1997. $541 \mathrm{p}$.

6. Billington, D.Kh. Ikona i topor: opyt istolkovaniia istorii russkoi kul'tury [Icon and axe: experience of interpretation of Russian culture history]. M., Rudomino, 2001. 880 p.

7. Bolotov, A.T. Zhizn' i prikliucheniia A. Bolotova, pisannye im samim dlia svoikh potomkov [The life and adventures of A. Bolotov, written by him to his descendants]. M., Sovremennik, 1986. $767 \mathrm{p}$.

8. Borodin, S.M. (1887). Gallofobiia v nashei literature proshlogo veka [Gallophobia in our literature of the last century]. Nabliudatel' (The observer), 10. Pp. 70-85.

9. Chudinov, A.V. Utopii veka Prosveshcheniia: kurs lektsii [Utopias of the Age of Enlightenment: lectures]. M., Institute of General History RAS, 2000. 90 p.

10. Cronk, N. The Cambridge Companion to Voltaire. Cambridge University Press, 2009. 235 p. Knapp, B. L. Voltaire Revisited. New York, Tiuayne, 2000. 228 p.

11. Davidson, I. Voltaire. A Life, London, Pegasus Books, 2010. 560 p.

12. Dmitrieva, E.E., Kuptsova, O.N. Zhizn' usadebnogo mifa: utrachennyi i obretennyi rai [The life of manor myth: paradise lost and found]. M., OGI, 2003. 528 p.

13. Filosoficheskaia i politicheskaia perepiska imperatritsy Ekateriny Vtoroi s Vol'terom, prodolzhavshaiasia s 1763 po 1778 gg. (Philosophical and political correspondence of the Empress Catherine II with Voltaire, which lasted from 1763 to 1778). In 2 vol. Vol. 1, 1802. M., 238 p.

14. Fonvizin, D.I. Chistoserdechnoe priznanie o delakh moikh i pomyshleniiakh [The sincere confession of my deeds and thoughts]. Collection of works, in 2 vol. Vol. 2. Moscow-Leningrad, 1959. Pp. 81-109.

15. Fonvizin, D.I. Dramaturgiia, poeziia, proza [Dramatic theory, poetry, prose]. M., Pravda, 1989. $432 \mathrm{p}$.

16. Karamzin, N.M. Melador k Filaretu [Melador to Filaret]. Izbrannye stat'i i pis'ma (Selected articles and letters). M., 1982. Pp. 147-152.

17. Labzina, A.E. Istoriia zhizni blagorodnpi zhenshchiny [The life story of a noble woman]. M., Novoe literaturnoe obozrenie, 1996. Pp. 13-89.

18. Lotman, Iu.M. Besedy o russkoi kul'ture: Byt i traditsii russkogo dvorianstva (XVIII - nach. XIX veka) [Conversations about Russian culture: everyday life and traditions of the Russian nobility (18 $18^{\text {th }}$ - beginning of the $19^{\text {th }}$ century). Saint-Petersburg, Iskusstvo, $1994.399 \mathrm{p}$.

19. Muller, J. Z. The Mind and the Market: Capitalism in Western Thought. Knopf: Anchor Books, 2002. 512 p.

20. Naidysh, V.M. Filosofiia mifologii [Philosophy of Mythology]. M., Gadariki, 2002. $554 \mathrm{p}$. 
21. Nechkina, M.V. (1948). Vol'ter i russkoe obshchestvo [Voltaire and Russian society]. Vol'ter. Stat'i i materialy (Voltaire. Articles and materials). Moscow-Leningrad. Pp.86-90.

22. Ovchinnikova, E.A. (2001). Russo i Vol'ter v kontekste religiozno-nravstvennykh iskanii russkikh myslitelei XVIII - nachala XIX v. [Rousseau and Voltaire in the context of religious and moral searches of Russian thinkers of the $18^{\text {th }}$ - beginning of the $19^{\text {th }}$ century]. Religiia i nravstvennost' v sekuliarnom mire: materialy nauchnoi konferentsii (Religion and morality in the secular world: proceedings of scientific conference). Saint-Petersburg. Pp. 175-183.

23. Pearson, R. Voltaire Almighty: a life in pursuit of freedom. Bloomsbury USA, 2005. 384 p.

24. Pen'kovskii, A.B. Nina. Kul'turnyi mif zolotogo veka russkoi literatury v lingvisticheskom osveshchenii [Nina. The cultural myth of the golden age of Russian literature in the linguistic coverage]. M., Indrik, 1999. 640 p.

25. Pis'ma russkikh masonov (Letters of Russian Freemasons) (1922). Golos minuvshego (Voice of the past), 2. Pp. 180-370.

26. Proskurina, V. Mify imperii: Literatura i vlast' v epokhu Ekateriny II [Myths of the Empire: literature and the power in the era of Catherine II]. M., Novoe literaturnoe obozrenie, 2006. 328 p.

27. Sol, D.R. Ubliudki Vol'tera. Diktatura razuma na Zapade [Voltaire's Bastards. Dictatorship of Reason in the West]. M., AST: Astrel', 2007. 895 p.

28. Stroev, A.F. "Te, kto ispravliaet Fortunu". Avantiuristy Prosveshcheniia ["Those who correct the Fortune". Adventurers of the Enlightenment]. M., Novoe literaturnoe obozrenie, 1998. 398 p.

29. Sushkov, M.V. (1979). Rossiiskii Verter [Russian Werther]. Russkaia sentimental'naia povest' (Russian sentimental novel). M., Publishing House of Moscow University. Pp. 203-223.

30. Trefolev, L.N. (1883). Predsmertnoe zaveshchanie russkogo ateista [Deathbed testament of the Russian atheist]. Istoricheskii vestnik (Historical bulletin), January. Pp. 224-225.

31. Valitskaia, A.P. Russkaia estetika XVIII veka [Russian aesthetics of the $18^{\text {th }}$ century]. M., Iskusstvo, 1983. $238 \mathrm{p}$.

32. Voltaire. Philosophical works: transl. from French. M., Nauka, 1996. 560 p.

33. Wolff, L. Izobretaia Vostochnuiu Evropu. Karta tsivilizatsii v soznanii epokhi Prosveshcheniia. [Inventing Eastern Europe. Map of civilization in the consciousness of the Enlightenment]. M., Novoe literaturnoe obozrenie, 2003. 560 p.

34. Wortman, R.S. Stsenarii vlasti. Mify i tseremonii russkoi monarkhii: ot Petra Velikogo do smerti Nikolaia I [Scenarios of power. Myths and ceremony of the Russian monarchy, from Peter the Great to the death of Nicholas I]. In 2 vol. Vol. 1. M., OGI, 2002. 605 p.

35. Zorin, A.L. "Kormia dvuglavogo orla": literature i gosudarstvennaia ideologiia v Rossii poslednei treti XVIII - pervoi treti XIX veka ["Feeding the double headed eagle": literature and state ideology in Russia of the last third of the $18^{\text {th }}$-the first third of the $19^{\text {th }}$ century]. M., Novoe literaturnoe obozrenie, 2001. $416 \mathrm{p}$. 


\section{Ономомифы Вольтера в русском литературном сознании эпохи Просвещения}

\section{Е.Е. Приказчикова}

Уральский федеральный университет имени Б.Н. Ельцина Россия, 620002, Екатеринбург, ул. Мира, 19

В статье представлен анализ пяти ономомифов Вольтера, созданных литературным сознанием эпохи Просвещения в России. На основе исследования данных ономомифов, видящих в Вольтере попеременно то бориа с религиозным фанатизмом, то полномочного министра ада, то вождя либертинцев, то вдохновителя «вольтерьянских» самоубийств, то организатора Франиузской революиии, автор приходит к выводу о внеисторическом характере культурного мифотворчества. Данное мифотворчество в новых литературноисторических условиях может возрождать и развивать старые мифологемы, относящиеся к вечной проблеме взаимоотношения личности и общества.

Ключевые слова: Вольтер, ономомифы, эпоха Просвещееня, культурная мифология.

Научная спечиальность: 10.00.00 - филологические науки. 